МОДЕЛЮВАННЯ ПРОЦЕСУ УПРАВЛІННЯ

НАВЧАЛЬНО-ТВОРЧОЮ ДІЯЛЬНІСТЮ СТУДЕНТІВ В УМОВАХ ПРОФЕСІЙНОЇ ПІДГОТОВКИ ІНЖЕНЕРІВ АГРАРНОГО ПРОФІЛЮ

\title{
A DESIGN OF PROCESS OF MANAGEMENT OF STUDENTS EDUCATIONAL-CREATIVE ACTIVITY IN THE CONDITIONS OF PROFESSIONAL PREPARATION OF ENGINEERS OF AGRARIAN TYPE
}

УДК 378.02: 372.8

DOI https://doi.org/10.32843/2663-

$6085 / 2020 / 22-2.29$

\author{
Нагаєв B.M., \\ докт. пед. наук, професор, \\ професер касредри організації \\ виробництва, бізнесу та менеджменту \\ Харківського національного технічного \\ університету сільського господарства \\ імені Петра Василенка \\ Бакум М.В., \\ канд. техн. наук, профресор, \\ просресор кафредри \\ сільськогосподарських машин \\ Харківського національного технічного \\ університету сільського господарства \\ імені Петра Василенка \\ Мітяшкіна Т.Ю., \\ канд. пед. наук, \\ доцент кафедри обладнання \\ та інжинірингу переробних і харчових \\ виробництв \\ Харківського національного технічного \\ університету сільського господарства \\ імені Петра Василенка \\ Семенцов В.В., \\ канд. тех. наук, \\ доцент кафредри технічних систем \\ та технологій тваринництва \\ Харківського національного технічного \\ університету сільського господарства \\ імені Петра Василенка
}

\begin{abstract}
Стаття присвячена одній із актуальних педагогічних проблем - моделюванню змісту професійної підготовки майбутніх фрахівців. Запропонована модель управління навчально-творчою діяльністю студентів у процесі профресійної підготовки майбутніх інженерів аграрного профілю представлена у вигляді семантичної мережі, початковими вершинами якої є вимоги освітньо-квалісрікаційних характеристик та освітньо-профессійних програм, а вершиною - сукупність критеріїв профресійно-творчої компетентності. Цільова фуункція досягнення освітнього результату описана логарифммічною фрункцією, у якій коефріцієнт управлінського впливу представлено елементами управління, співуправління та самоуправління навчально-творчою діяльністю студентів. Графрічна модель сфрормованості профресійної компетентності в системі управління навчально-творчою діяльністю студентів визначена за показниковою фрункцією.

Експериментальне дослідження проводилося на базі Харківського національного технічного університету імені Петра Василенка на прикладі навчальних дисциплін, що формують профессійну компетентність майбутніх фрахівців на бакалаврському та магістерському освітніх рінях спеціальності 208 «Агроінженерія». Результатами дослідження підтверджено адекватність моделі прочесу управління навчально-творчою діяльністю студентів під час професійної підготовки інженерних кадрів аграрного профбілю. Реалізація математичної моделі управління навчально-творчою діяльністю студентів забезпечує візуалізацію педагогічних умов активізації дидактичних процесів $і$ організаційно-технологічних алгоритмів в умовах управління, співуправління та самоуправління навчально-творчою діяльністю студентів і, як наслідок, підвищення якісних характеристик профресійно-творчої компетентності майбутніх інженерів аграрного просрілю.

Ключові слова: професійна підготовка інженерів аграрного профрілю, професійно-творча компетентність, управління
\end{abstract}

навчально-творчою діяльністю студентів математична модель сформованості професійно-творчої компетентності майбут ніх інженерів аграрного профілю.

The article is sacred to one of pedagogical issues of the day - to the design of maintenance of professional preparation of future specialists. The offered model of students educational-creative activity frame in the process of professional preparation of future engineers of agrarian type is presented as a semantic network the initial tops of which are requirements of educationally-qualifying descriptions and educationally-professional programs, and by a finishing top is an aggregate of criteria of professionally-creative competence. The objective function of achievement of educational result is described by a logarithmic function in which the coefficient of administrative influence is presented by custom controls, comanagement and self-government of students educational-creative activity. The graphic model of formed of professional competence in control system of educational-creative activity of students is certain after an indicator function.

Experimental research was conducted on the base of the Kharkiv national technical university of agriculture of the name Petro Vasylenko on the example of educational disciplines which form the professional competence of future specialists on a bachelor and master's degree to educational levels speciality 208 "Agrarian engineering". Realization of mathematical case of students educational-creative activity frame provides visualization of pedagogical terms of activation of didactics processes and organizational and technological algorithms in the conditions of management, co-management and selfgovernment educational-creative activity froze, as a result, increase of high-quality descriptions of professionally-creative competence of future engineers of agrarian type.

Key words: professional preparation of engineers of agrarian type, professionally-creative competence, management of students educational-creative activity, mathematical model of formed of professionally-creative competence of future engineers of agrarian type.
Постановка проблеми у загальному вигляді. Удосконалення освітньої системи в Україні має забезпечити наповнення педагогічної системи креативним змістом навчання відповідно до суспільного запиту на підготовку творчо обдарованих інженерів аграрного профрілю. Одним із основних критеріїв реалізації концепції креативної моделі навчання має стати управлінський підхід в умовах керуючої ролі викладача і самоуправління студента. Саме викладач повинен організувати педагогічні умови активної навчально-творчої діяльності (далі - НТД), створивши відповідне творче освітнє середовище. Студент відповідно до індивідуальних потреб, інтересів і мотивів має спланувати особистісну стратегію самоуправління НТД. Така творча співпраця в сучасних умовах може бути досягнута завдяки високому рівню творчої співпраці, технологізації, інорорматизації та методичного забезпечення в умовах цифррової педагогіки [11].

Педагогічна система творчого рівня освіти в умовах управління НТД студентів вимагає глибокого й істотного відображення новітніх тенденцій і явищ у процесі професійної підготовки майбутніх інженерів аграрного профрілю на рівні досягнення 
досвіду творчої діяльності. Ці аспекти доводять необхідність проектування організаційно-управлінських моделей професійної підготовки інженерних кадрів, які б забезпечували досягнення гарантованого рівня професійно-творчої компетентності (ПТК) майбутніх фрахівців [1-3].

Аналіз останніх досліджень і публікацій. Навчальний процес за умов впровадження елементів циоррової педагогіки має бути сорормований за сучасними принципами дидактики, які включають елементи технологічності, управління (співуправління, самоуправління), індивідуалізації, мотиваційного забезпечення та ін. Реалізація цих принципів дозволяє забезпечити ефективне професійно-творче зростання майбутніх фрахівців за умов суттєвого підвищення функціонального управління дидактичними процесами [13, с. 124]. Попередні дослідження у цій галузі довели, що при створенні викладачем у навчальному процесі творчого освітнього середовища відповідно до потреб здобувачів творча активність останніх збільшується на третину, що у підсумку призводить до підвищення на 20\% досвіду творчої діяльності майбутніх орахівців на виробництві [8-9].

П.Г. Лузан підкреслює, що творча навчальнопізнавальна активність як інтегрована властивість, міра діяльності та розвитку особистості повинна фрормуватися поетапно, від репродуктивних, виконавчих рівнів до продуктивних, творчих. Саме тому ефективність навчання пов'язується 3 цілями активізації, коли послідовне оволодіння рівнями засвоєння знань (розпізнаванням, запам'ятовуванням, розумінням, умінням, перенесенням знань, оцінкою) підпорядковується головній меті - фрормуванню продуктивних пізнавальних потреб і мотивів навчання [4, с. 125].

Поступове сходження здобувачів за рівнями творчого досвіду має відбуватися на основі технологічного підходу в умовах управління НТД студентів, яка розглядається як об'єкт цілеспрямованого впливу суб'єктів педагогічного процесу - викладачів і студентів. Характер прояву творчої активності здобувачів залежить від багатьох фракторів: педагогічної майстерності викладача, рівня підготовленості студентів, впровадження інноваційних освітніх технологій, дидактичних засобів та інших педагогічних умов [5; 7].

Виділення не вирішених раніше частин загальної проблеми. Незважаючи на результати наукових пошуків у галузі професійної підготовки майбутніх інженерів агропромислового виробництва, поза увагою дослідників залишилися важливі теоретико-методичні аспекти моделювання змісту професійної підготовки майбутніх фрахівців цієї галузі на основі організаційних і математичних моделей управління НТД студентів.

Мета статті полягає у проектуванні моделі управління НТД студентів у процесі фрахової під- готовки майбутніх інженерів аграрного профрілю на основі фрормування творчого досвіду як освітнього результату.

Виклад основного матеріалу. Враховуючи особливості НТД як об'єкта дослідження, вважаємо, що найбільш адекватно відображають процеси управління НТД освітні моделі, в основу яких покладений принцип функціонування семантичних мереж [6].

Семантичні мережі становлять часткову модель теорії графрів, яка визначає процес досягнення освітнього результату шляхом поступового сходження об'єкта за вузловими дидактичними вершинами відповідно до навчальних цілей. Семантична мережа в умовах навчального процесу $€$ управлінською моделлю досягнення освітніх результатів на основі створення мережі дидактичних вузлів. Дидактичні вузли відповідають певним освітнім поняттям (категоріям) або об'єктам, котрі поєднуються між собою тематичними зв'язками та педагогічними відносинами (дугами). Представлення освітнього результату у вигляді апарату семантичних мереж полягає у тому, що предметна галузь розглядається як сукупність об'єктів (понять) і педагогічних відносин між ними. Під предметною галуззю слід розуміти педагогічні процеси (їх стан і розвиток), які можна описати сукупністю властивостей об'єктів, що їх створюють, і зв'язками між ними.

Представимо модель управління НТД студентів у вигляді семантичної мережі, початковими вершинами якої $€$ вимоги освітньо-квалісікаційних характеристик (OKX) та освітньо-професійних програм (ОПП), а завершальною вершиною - сукупність освітніх критеріїв: компетентнісні характеристики професійної діяльності, творчий досвід, рівень самостійності та індивідуалізації, науковий рівень підготовки, системність мислення, спроможність фрормування нестандартних підходів до прийняття рішень тощо. Отримання освітніх результатів здійснюється на основі педагогічного впливу функціональних дидактичних вузлів, вершинами яких $€$ управлінські фрункції: планування, організація, мотивація, контроль та аналіз [12, с. 124]. НТД визначається різноманітним характером відносин між компонентами педагогічної системи (рис. 1).

Проміжні вершини семантичної мережі відповідатимуть окремим видам педагогічного впливу: відповідним фуункціям управління (плануванню, організації, мотивації, контролю, регулюванню). Оскільки НТД є співпрацею педагога і студента, необхідно вважати проміжними вершинами також фрункції самоуправління студентів: самопланування, самоорганізацію, самомотивацію, самоконтроль. Рівень і напрями взаємовідносин суб'єкт-суб'єктних вершин залежать від освітніх цілей і предметної галузі, що визначатиме відпо- 


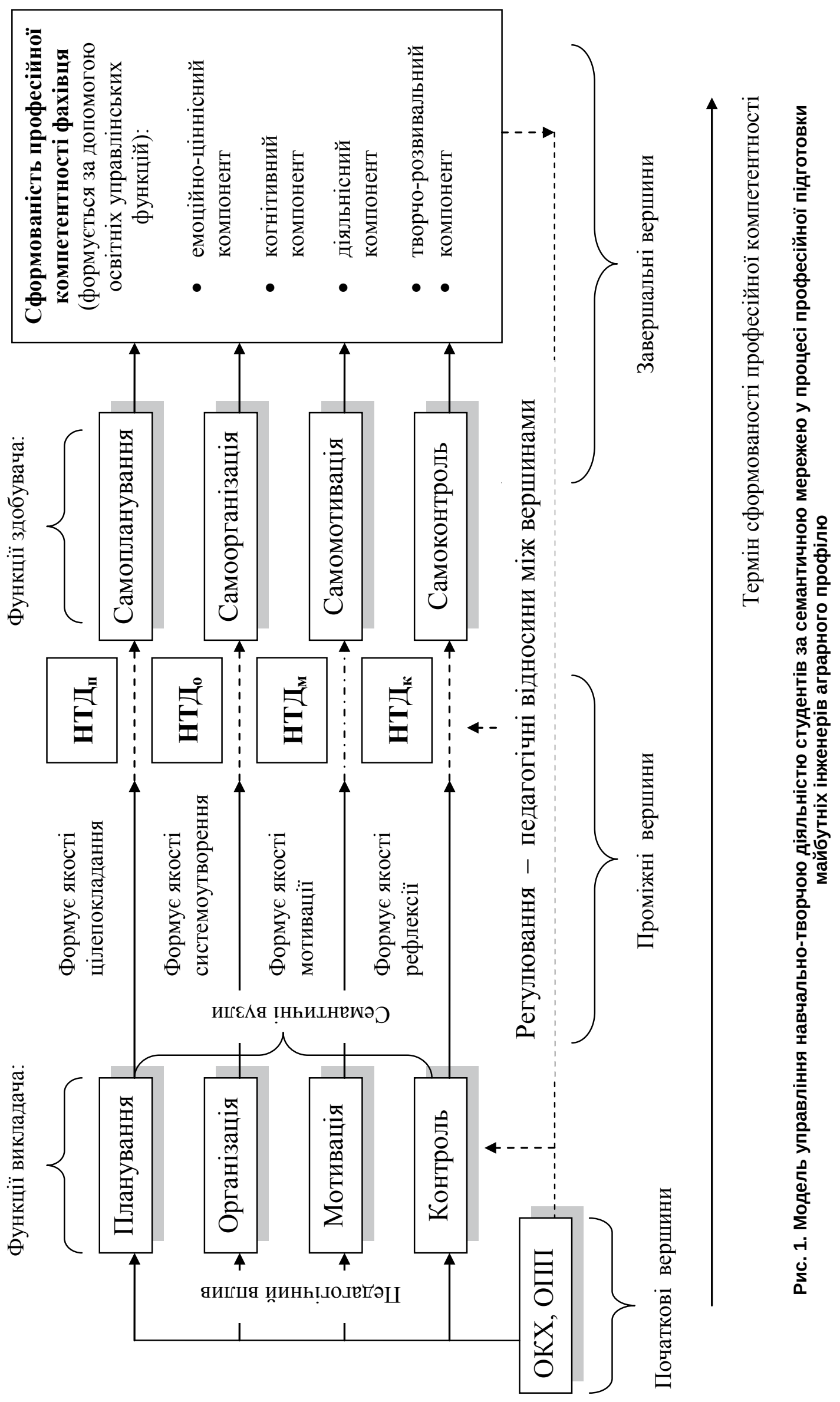


відні методи, форми та дидактичні засоби педагогічної співпраці [10].

Метою моделі управління НТД за семантичною мережею $є$ : підвищення ефрективності фрормування професійної компетентності майбутнього інженера аграрного профрілю на основі розвитку творчо обдарованої особистості.

Частковими цілями процесу управління НТД студентів $є:$ 1) підвищення рівня підготовки фрахівців за емоційно-ціннісним, когнітивним, діяльнісним і творчо-розвивальним компонентами; 2) оптимізація дидактичних форм і методів навчання на основі впровадження творчого освітнього середовища; 3) підвищення продуктивності процесу навчання в умовах обмеженості часу підготовки спеціалістів; 4) підвищення рівня самостійності та індивідуалізації НТД студентів на основі розвитку емоційно-ціннісних і мотиваційних аспектів особистості; 4) оптимізація педагогічних взаємозв'язків у системі «викладач - студент», «студент - студент», «студент - ТЗН» та ін. на основі розвитку автодидактичних фрункцій 5) оптимізація критеріїв якості підготовки фрахівців за моделлю ПТК.

У цій семантичній мережі задані педагогічні відносини різних типів (що відповідає неоднорідній семантичній мережі). Крім того, семантичні вузли (вершини) мають власну структурну побудову й ієрархію впливу на об'єкт управління, і це говорить про наявність ієрархічної семантичної мережі. Так, семантичний вузол функції планування може мати таку структуру НТД студента:

1) формування системи навчальних цілей за критеріями ПТК майбутніх орахівців;

2) розробка програми НТД студентів за цільовим підходом;

3) планування індивідуальної стратегії самонавчання студентів за кредитно-модульними програмами;

4) розробка технологічних карток-пам'яток із самостійного вивчення дисципліни за кредитномодульною технологією навчання;

5) планування навчально-дослідної роботи студентів;

6) формування навичок студентів індивідуального планування робочого часу в системі самоуправління НТД;

7) операційне нормування елементів НТД студентів за критеріями ПТК майбутніх фрахівців.

Семантичний вузол функції організації має таку структуру НТД:

1) фрормування якостей системоутворення дидактичних процесів;

2) організація денного розпорядку НТД студента з визначенням технологічних процесів, дій і операцій;

3) регламентація педагогічних процесів у системі організації НТД;
4) організація самостійної та індивідуальної роботи студентів;

5) організація механізмів і фрорм співпраці в системах «студент - викладач», «студент - студент», «студент - група», «студент - ТЗН» та ін.;

6) застосування системи дидактичних методів, форм і засобів управління НТД за мотиваційними потребами студентів;

7) розробка системи інфрорматизації НТД.

Семантичний вузол фрункції мотивації має таку структуру НТД:

1) аналіз цілей і мотивів НТД студентів;

2) фрормування мотиваційної структури НТД студентів;

3) задоволення індивідуальних і колективних потреб студентів стосовно активізації НТД;

4) фрормування системи морального заохочення НТД студентів з урахуванням індивідуального підходу до стимулювання;

5) фрормування сприятливих соціально-психологічних відносин у системі цілей НТД: «студент - викладач», «студент - студент», «студент група»;

6) підвищення рівня задоволеності НТД у контексті формування здорових потреб особистості;

7) розробка нетрадиційних способів і фрорм спонукання (самомотивації) високопродуктивної НТД студентів.

Семантичний вузол ффункції контролю й аналізу НТД:

1) фрормування й аналіз критеріїв НТД студентів;

2) контроль (самоконтроль) рівня сорормованості ПТК;

3) визначення методів і фрорм контролю НТД студентів;

4) організація модульного контролю НТД студентів;

5) організація системи поетапного контролю НТД студентів;

6) організація контролю в системі ігрових методів навчання;

7) організація контролю НТД за дистанційною формою навчання.

Семантичний вузол функції координації та регулювання має таку структуру НТД:

1) узгодження фрункцій управління та самоуправління НТД студентів за цілями діяльності;

2) оптимізація елементів централізації та децентралізації управління НТД залежно від рівня творчої спрямованості фрахової підготовки кадрів;

3) корекція методів управління НТД залежно від рівня досягнення навчальних цілей за результатами проміжного контролю й аналізу;

4) корекція навчальних дій за результатами НТД студентів;

5) координація цілей НТД студентів у структурі цільової програми підготовки фрахівців за критеріями ПТК; 
6) забезпечення надійного зв'язку між елементами педагогічної системи;

7) організація вертикальної та горизонтальної педагогічної комунікації в системі НТД студентів («викладач - студент», «студент - студент», «студент - група», «студент - ТЗН»).

Загальну залежність рівня сфрормованості ПТК майбутніх інженерів аграрного профілю (Сптк) від рівня досягнення критеріальних показників НТД $\left(\mathrm{x}_{1}, \mathrm{x}_{2} \ldots \mathrm{x}_{\mathrm{n}}\right)$ в умовах управління за сукупністю фрункцій планування, організації, мотивації, контролю та регулювання $\Sigma(П, \mathrm{O}, \mathrm{M}, \mathrm{K}, \mathrm{P})$ можна представити фрункцією досягнення початкових, проміжних і завершальних вершин:

$$
\begin{gathered}
\mathrm{C}_{\text {птк }}=f\left\{\sum \Pi\left(\mathrm{x}_{\mathrm{n}}\right)+\sum \mathrm{O}\left(\mathrm{x}_{\mathrm{n}}\right)+\sum \mathrm{M}\left(\mathrm{x}_{\mathrm{n}}\right)+\right. \\
\left.\sum \mathrm{K}\left(\mathrm{x}_{\mathrm{n}}\right)+\sum \mathrm{P}\left(\mathrm{x}_{\mathrm{n}}\right)\right\},
\end{gathered}
$$

де: $\sum(П, \mathrm{O}, \mathrm{M}, \mathrm{K}, \mathrm{P})$ - функції проміжної вершини (планування, організація, мотивація, контроль, регулювання); $\left(x_{n}\right)$ - критерії дидактичних вершин (показники рівня сорормованості ПТК за відповідною фрункцією управління).

Творчі компоненти професійної компетентності визначаються розливальною функцією особистості на основі її постійного розвитку під впливом освітніх процесів. Якщо вважати творчість постійно зростаючою характеристикою психологічної структури особистості, можна запропонувати загальну математичну модель процесу досягнення рівня сорормованості ПТК у вигляді степеневої математичної фрункції

$$
\mathrm{P}=A *\left(x_{1}^{a}+x_{2}^{b}+\ldots x_{n}^{c}\right)
$$

де: $\mathrm{P}$ - умовне визначення досягнутого рівня сорормованості ПТК у процесі управління НТД; А постійний коефіцієнт, що відображає зв'язок рівня сорормованості ПТК зі значеннями фракторних ознак і організаційним рівнем управління; $\mathrm{X}_{1} \ldots \mathrm{X}_{\mathrm{n}}$ умовне визначення фракторних ознак, що враховуються як критерії ПТК у визначенні цієї фрункції; а, в, с - показники степені при чисельних значеннях фракторних ознак.

Чисельні значення усіх фракторних ознак встановлюються емпірично, на основі репрезентативної вибірки систематизованого матеріалу пошукових педагогічних досліджень. Загальну модель опису процесу управління НТД проектуємо на основі регресійно-кореляційного аналізу комп'ютерної програми «Статистика-6», що визначає параметри постійних коефіцієнтів і відповідні степені фракторних ознак. Враховуючи попередній фракторний аналіз характеру навчального процесу підготовки майбутніх інженерів аграрного профрілю за критеріями ПТК, математичний опис процесу управління НТД із досягненням освітнього результату - рівня сорормованості ПТК $\left(\mathrm{P}_{\text {птк }}\right)$ можна представити степеневою (квадратичною) фрункцією за фрормулою:

$$
\mathrm{P}_{\text {птк }}=A * \sqrt{\sum_{i=1}^{n} B *\left(x_{1}+x_{2}+\ldots x_{n}\right)},
$$

де: А - коефіцієнт фрункціонального управлінського впливу на НТД, що відображає зв'язок рівня сорормованості ПТК з управлінськими функціями педагога і фрункціями автодидактики здобувача; В - коефіцієнт, що характеризує рівень організації освітнього середовища; $\left(\mathrm{X}_{1}, \mathrm{X}_{2} \ldots \mathrm{X}_{\mathrm{n}}\right)-$ фракторні ознаки (критеріальні показники сорормованості ПТК).

Коефріцієнт управлінського впливу (A) $€$ інтегрованим показником, який визначається процесами управління 3 боку викладачів і процесами співуправління і самоуправління з боку студентів. Цей функціональний вплив на НТД визначає продуктивність досягнення студентами відповідного рівня сорормованості компонентів ПТК. Можна вважати, що коефіцієнт управлінського впливу на НТД дорівнює:

$$
A=\alpha_{1}+\alpha_{2}+\alpha_{3},
$$

де: $\alpha_{1}-$ коефріцієнт управління, $\alpha_{2}-$ коефіцієнт співуправління, $\alpha_{3}-$ коефріцієнт самоуправління.

Представлені функціональні складові частини математичної моделі в сукупності визначають комплексний управлінський вплив на НТД студентів, що визначається сукупністю дій та операцій педагогічного, психологічного й організаційного характеру.

Результати дослідження. Результати науковопедагогічних досліджень із вивчення характеру процесу досягнення студентами цілей навчання дають підстави вважати, що графічно модель управління процесом досягнення певного рівня сорормованості ПТК можна представити як нелінійну параболічну залежність. Функціонально графріком цієї фрункціональної моделі $€$ вітка параболи: $\mathrm{Y}=\mathrm{X}^{2} \quad(\mathrm{X} \geq 0)$ відносно прямої $\mathrm{Y}=\mathrm{X}$ (рис. 2).

Емпірична крива (1) побудована за усередненими даними аналізу досягнення студентами рівня сорормованості ПТК протягом навчального року на підставі педагогічних експериментів у ХНТУСГ ім. Петра Василенка. Експериментальні дослідження проводилися на прикладі вивчення профресійноорієнтованих навчальних дисциплін, що формують професійну компетентність майбутніх інженерів аграрного профрілю на бакалаврському та магістерському освітніх рінях спеціальності 208 «Агроінженерія». Експериментальні групи навчалися за педагогічною моделлю управління НТД, а контрольні - за традиційною системою навчання.

Розглядаючи характер емпіричної (1) та теоретичної (2) кривої на рис. 2, слід зазначити, що найбільш точно відображає ії̈ апроксимацію логарифрмічна фрункція. За допомогою програмного забезпечення «Статистика-6» нами було проведено вирівнювання емпіричної кривої за логарифрмічною функцією. Ця функція зростає на всій області визначення у часі.

Тобто за умов процесів ефективного управління, співуправління та самоуправління НТД 


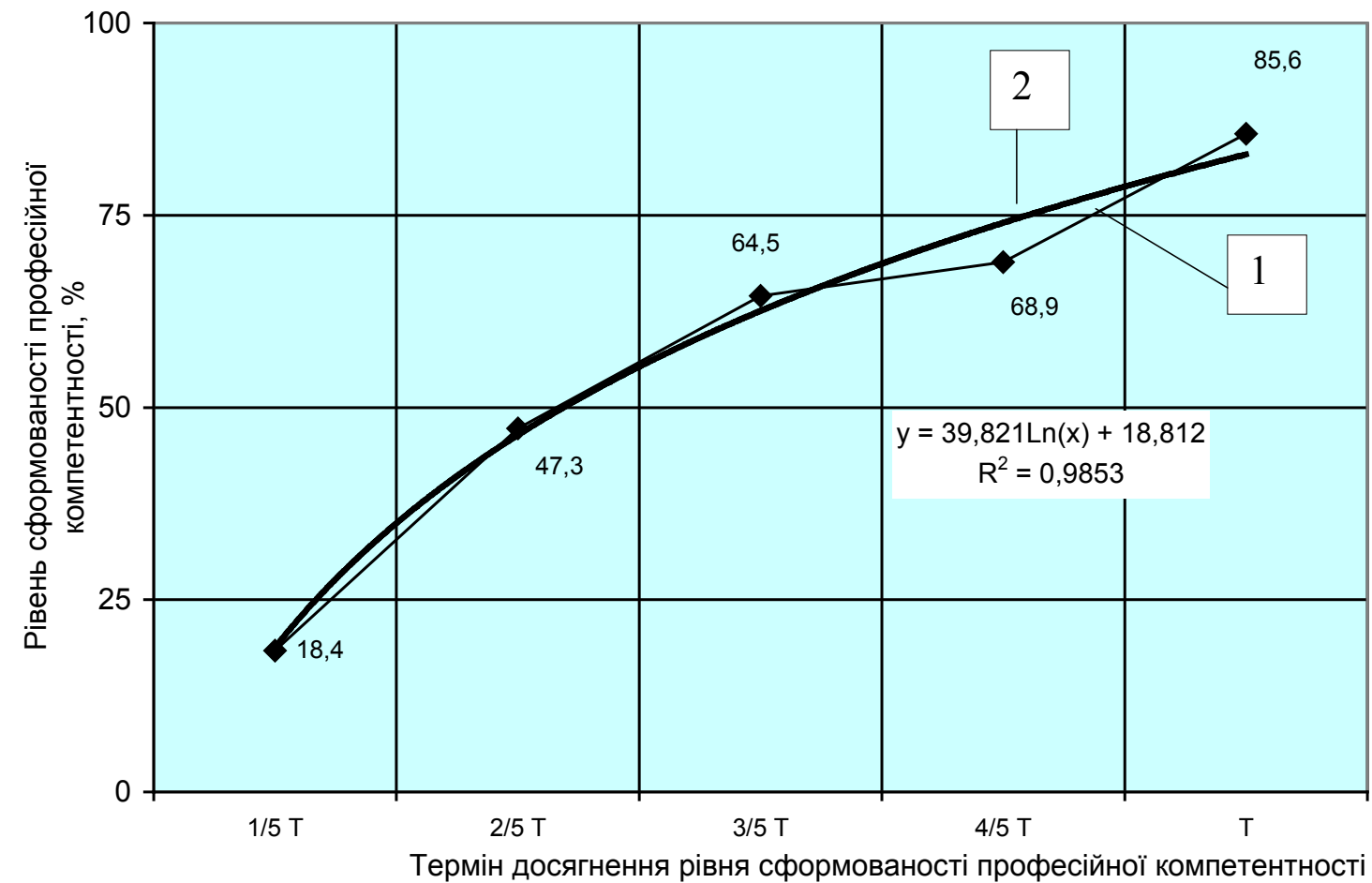

Рис. 2. Графічна модель сформованості професійної компетентності майбутніх інженерів аграрного профілю в системі управління НТД студентів

(високий коесріцієнт фрункціонального впливу) і збільшення рівня досягнення критеріальних показників ПТК майбутніх фрахівців $\left(\mathrm{x}_{1}, \mathrm{x}_{2} \ldots\right.$ $\mathrm{x}_{n}$ ) в умовах творчого освітнього середовища маємо більш високий рівень сформованості показників ПТК майбутніх інженерів агропромислового виробництва $\left(P_{\text {птк }}\right)$. Область визначення цієї функції є множина, не симетрична відносно початку координат:

$$
\mathrm{y}^{\mathrm{x}}=1,5206 \operatorname{Ln}(\mathrm{x})+0,565 .
$$

Рівень управлінського впливу коефіцієнта «А» на критеріальні показники $\mathrm{X}_{(1-n)}$ визначає продуктивність процесу досягнення рівня сорормованості ПТК, що відображається рівнем кривизни графіка.

Для визначення адекватності моделі скористаємося методом найменших квадратів. Розрахунки відхилень показників (У) на визначеному проміжку часу для емпіричної та теоретичної кривої повинні бути такими:

$$
\sum \delta_{\mathrm{i}}=\sum\left(\mathrm{y}_{\mathrm{i}}-y_{i}^{*}\right)=S_{1} \supseteq 1 .
$$

Коефріцієнт детермінації $\left(\mathrm{R}^{2}\right)$ наближається до одиниці. Отже, процес досягнення визначеного рівня сорормованості ПТК майбутніх інженерів аграрного профрілю за умов управління НТД можна описати математичною моделлю у вигляді логарифрмічної dрункції:

$$
\mathrm{y}_{\text {рстд }}=\ln A \sum_{\mathrm{i}=1}^{\mathrm{n}} \mathrm{B}\left(\mathrm{x}_{1}+x_{2}+\ldots x_{n}\right) \text {, }
$$

де: A - коефріцієнт фрункціонального управлінського впливу на НТД в умовах управління, співуправління та самоуправління $(A>0$ і $A \neq 0)$; в - коефріцієнт, що характеризує рівень організації освітнього середовища; $\left(\mathrm{x}_{1}, \mathrm{x}_{2} \ldots \mathrm{x}_{\mathrm{n}}\right)$ - критеріальні показники засвоєння творчого досвіду).

Функція є зростаючою за умов: $A>1$. Кут нахилу логарифмічної кривої буде визначати продуктивність процесу сорормованості ПТК і характеризуватися рівнем функціонального впливу на критеріальні показники ПТК в умовах управління (з боку викладачів і ТЗН), співуправління та самоуправління (з боку студентів).

Висновки. Запропонована модель процесу профресійної підготовки майбутніх інженерів аграрного профрілю в умовах управління НТД студентів представлена у вигляді семантичної мережі, початковими вершинами якої $€$ вимоги освітньо-кваліфрікаційних характеристик та освітньо-професійних програм, а завершальною вершиною - сукупність критеріїв ПТК компетентності (емоційно-ціннісний, когнікативний, діяльнісний, творчо-розвивальний компоненти).

Сфрормованість ПТК здійснюється на основі педагогічного впливу функціональних дидактичних вузлів, вершинами яких $є$ управлінські функції: планування, організація, мотивація, контроль, регулювання. Математична модель процесу формування ПТК досягнення творчого досвіду студентів за умов управління НТД представлена логарифмміною (квадратичною) функцією. Продуктивність досягнення освітнього результату визначається рівнем функціонального впливу на НТД з боку викладача, а також рівнем співуправління та самоуправління з боку студента. 
Отримані результати дозволили визначити шляхи подальших науково-педагогічних досліджень у цьому напрямі: розробку інфрормаційних електронних методичних систем навчально-методичного забезпечення в умовах фрормування ПТК майбутніх інженерів аграрного профрілю; впровадження досвіду застосування педагогічних SMART-технологій управління НTД студентів.

\section{БІБЛІОГРАФІЧНИЙ СПИСОК:}

1. Брюханова Н.О. Основи педагогічного проектування в інженерно-педагогічній освіті : монографрія. Харків : НTMT, 2010. 438 с.

2. Кошук О.Б. Проектування змісту профеесійної підготовки майбутніх інженерів 3 механізації сільського господарства. International scientific conference "Modernization of educational system: word trends and national peculiarities": Conference Proceedings. Kaunas: Izdevnieciba «Baltija Publishing», 2018. P. 146-150.

3. Лазарєва Т.А. Моделювання змісту творчого навчання 3 технологічного обладнання харчової галузі інженерів-технологів. Проблеми інженернопедагогічної освіти. 2012. Вип. 37. С. 81-87.

4. Лузан П.Г., Каленський А.А. Методи і фрорми організації навчання фрахівців аграрної галузі : навчальний посібник. Київ : Логос, 2014. 280 с.

5. Манько В.М. Методологічні аспекти розробки моделі інженера-механіка сільськогосподарського виробництва. Науковий вісник НАУ. 2000. Вип. 30. С. 24-32.
6. Метешкин К.А. Кибернетическая педагогика (теоретические основы управления образованием на базе интегрированного интеллекта) : монография. Харьков : МСУ, 2004. 400 с.

7. Нагаєв В.М. Методологічні засади управління навчально-творчою діяльністю студентів : монографрія. Харків : Стильна типографрія, 2018. 151 с.

8. Нагаєв В.М. Дидактичні засади впровадження дворівневої педагогічної технології управління навчально-творчою діяльністю студентів вищих навчальних закладів : монографрія. Харків : Колегіум, 2012. 217 c.

9. Нагаєв В.М. Формування професійно-творчої компетентності фрахівця аграрної ссрери. Наукові праці Полтавської державної аграрної академії. 2012. № 2 (5). T. 1. С. 184-189.

10. Нагаєв В.М. Методичні рекомендації по впровадженню модульно-рейтингової технології навчально-творчої діяльності студентів (із дисциплін управлінського циклу). Харків : ХНАУ, 2002. 76 с.

11. Ніколаєнко С.М. Шляхи модернізації та головні напрями інноваційного розвитку вищої освіти. Розвиток сучасної освіти: теорія, практика, інновації : зб. матеріалів між нар. наук.-практ. конфр., Київ, 14-16 травня 2015 р. Київ : Міленіум, 2015. С. 27-29.

12. Основи сучасної педагогіки : монографрія / Т.О. Дмитренко, К.В. Яресько, В.М. Нагаєв та ін. Херсон : Вид-во ПП Вишемирський В.С., 2016. 462 с.

13. Розвиток творчого потенціалу майбутнього фрахівця : монографрія / Т.О. Дмитренко, К.В. Яресько, Т.В. Колбіна та ін. Херсон : ПП Вишемирський В.С., 2014. 424 C. 